naalisen roolin perusteella. Joidenkin tulkintojen äärelle lukijaa olisi voinut taluttaa tiiviimmin perustellen. Paikoin lukija saa miettiä hyvin tarkkaan, millä perusteella tämä vuoro nyt olikaan evaluointi.

Kuitenkin tällainen ponnistelu on väistämätöntä silloin, kun ollaan uudenlaisen ajattelun tai näkemyksen äärellä. Teoksen kaikki yhteenvetoluvut, myös analyysiosassa, ovat hyvin selkeitä ja esittävät kulloisenkin ilmiön tyhjentävästi. Tässä työssä ollaan näennäisesti tutun kontekstin, aineiston ja toiminnan sijaan tekemisissä hyvinkin uudenlaisten toiminnan tutkimuksen näkökulmien kanssa. Kirjan luettuaan näkee evaluoinnin eri silmin kuin ennen, ja se on tutkimukselle ja teokselle suuri meriitti. Heinosen aihe on erittäin haastava, mutta tekijä on onnistunut rajaamaan tutkimusongelman perustellun ytimekkäästi. Tutkimus tuottaa uutta tietoa yhteiskunnalli- sesti tärkeästä aiheesta, jonka tieteellinen käsittely on pitkään kulkenut samaa uraa kyseenalaistamatta aiempaa tutkimusta. Tämän tuloksena luokkahuonevuorovaikutuksen tutkimuskentällä on syntynyt paljon pitkälti vain aiempaan tutkimukseen pohjaavaa vuorovaikutuksen kuvailua. Heinosen tutkimustulokset ovat ansiokkaita, ja niitä on mahdollista soveltaa melko suoraan myös opettajankoulutukseen tai jopa mallintaa pidemmälle, vaikkapa osaksi suomalaista koulutusvientiä. Teosta voi suositella jokaiselle opettajalle ja sellaiseksi aikovalle.

$$
\begin{array}{r}
\text { MIA HALONEN } \\
\text { etunimi.m.sukunimi@jyu.fi } \\
\text { Kirjoittaja on yliopistotutkija } \\
\text { Soveltavan kielentutkimuksen keskuksessa } \\
\text { Jyväskylän yliopistossa ja suomen kielen } \\
\text { dosentti Helsingin yliopistossa. } \\
\text { Hän toimi Heinosen vastaväittäjänä. }
\end{array}
$$

\title{
Merkkiteos itämerensuomalaisten esihistorian tutkimuksessa
}

Valter Lang: Läänemeresoome tulemised. Muinasaja teadus 28. Tartu Ülikooli Kirjastus 2018. 320 s. ISBN 978-994-977-662-7.

Etelänaapurissamme ilmestyi itsenäisyyden satavuotisjuhlan aikoihin harvinaislaatuinen teos: Tarton yliopiston arkeologian professori Valter Langin monografia itämerensuomalaisten kansojen ja kielten esihistoriallisesta syntyprosessista. Erityiseksi kirjan tekee se, että siinä on yhden tutkijan voimin koottu monitieteisen tutkimuksen viimeisimmät - osin vie- läpä aiemmin julkaisemattomat - tulokset johdonmukaiseksi ja yleistajuiseksi kokonaisesitykseksi. Kirjan laajaan ja monipuoliseen lähdeaineistoon kuuluu tutkimuksia niin kielitieteen, arkeologian, historian, ilmastotieteen kuin paleogenetiikan aloilta. Humanistisen tutkimuksen parhaitten perinteitten mukaisesti kirjoittaja on hyödyntänyt kaikilla tutkitun alueen valtakielillä - viroksi, suomeksi, ruotsiksi, tanskaksi, saksaksi, englanniksi, liettuaksi, latviaksi ja venäjäksi - kirjoitettuja lähteitä. Läänemeresoome tulemised 
vie meidät pitkän matkaa eteenpäin niistä esihistoriantutkimuksen näkymistä, joihin Kaisa Häkkisen Suomalaisten esihistoria kielitieteen valossa (1996) ja Tapani Lehtisen Kielen vuosituhannet (2007) toivat meidät viime vuosikymmeninä.

Mennyttä aikaa tutkiessa yhtenäisen kokonaisnäkemyksen tavoittelu johtaa valitettavan usein tieteellisestä tarkkuudesta ja kriittisyydestä tinkimiseen. Nyt niin ei ole käynyt: Läänemeresoome tulemised on esikuvallinen tieteellinen monografia. Ennen kaikkea Langin teos on ensimmäinen etnisen paradigman jälkeinen kokonaisesitys itämerensuomen esihistoriasta. Lang ei itse käytä termiä etninen paradigma, jolla tässä tarkoitan kieliyhteisön ja arkeologisen kulttuurin samastamista ja siihen usein liittyvää yhteisen geeniperimän, "antropologisen tyypin" tai "rodun" oletusta (vrt. Ligi 1995; Salminen 2013).

\section{Kirjan rakenne ja pääteesit}

Koska etninen paradigma hallitsi esihistorian tutkimusta koko 1900-luvun ja vielä vuosituhannen vaihteessakin, Lang joutuu purkamaan paradigman alkutekijöihinsä osoittaakseen sen teoreettisen perustan heikoksi. Tästä johtuu tutkimushistorian vahva osuus Langin kirjassa. Ensimmäisessä luvussa hän kuvaa kaikki 1800 -luvulta lähtien tieteellisinä argumentoidut kokonaisteoriat itämerensuomalaisten alkuperästä: vanhan kansainvaellusteorian, Alfred Hackmanin maahanmuuttoteorian, Harri Mooran kampakeraamisen jatkuvuusteorian ja siihen pohjautuvan Jorma Koivulehdon teorian sekä lopuksi Kalevi Wiikin koulukunnan suositun mutta heikosti perustellun ensiasutusteorian. Toisessa luvussa Lang esittelee nykyisen, vielä muovautumassa olevan käsityksen uralilaisen kielen pronssikautisesta leviämisestä länteen ja muuntumisesta kantasuomeksi Itämeren itärannalla. Lang onnistuu erin- omaisesti havainnollistamaan paitsi teorioitten taustoja myös niitten sisäisiä ristiriitaisuuksia, jotka pakottivat tutkijat etsimään uusia ratkaisuja ja siten viemään tiedettä eteenpäin.

Kolmas luku käsittelee esihistoriaa tutkivien eri alojen yhteensovittamisen metodiikkaa. Etnisen paradigman hylkääminen on Langin mukaan (s. 16) johtanut kielitieteen, arkeologian ja paleogenetiikan tulosten yhteensovittamisesta luopumiseen, joten hänen täytyy hahmotella eri alojen yhteistyölle kokonaan uudet, kestävät ehdot. Vasta tulevien vuosikymmenten tutkimus pystyy osoittamaan, kuinka hyvin Lang on siinä onnistunut, mutta edeltäjiensä virheitä hän ei ainakaan toista.

Kunkin esihistoriatieteen tutkimustulokset ovat autonomisia, mutta kaikki ne tukevat toisiaan. Työnsä kannalta tärkeimmät DNA-tutkimuksen ja historiallisen fennougristiikan tulokset Lang esittelee lyhyesti jo teoksen johdannossa ja täydentää kuvausta kolmannessa luvussa. Geneettiset erot nykyvirolaisten ja Viron alueen neoliittisen ajan väestöjen välillä viittaavat ainakin yhteen kivikauden jälkeiseen muuttoaaltoon (s. 17), joka puolestaan on yhdistettävissä uralilaisen kantakielen leviämiseen VolganKaman alueelta länteen pronssikauden taitteessa. Leviämisestä seurannut länsikantauralin jakautuminen saa terminus post quemin itämerensuomen viimeisiltä, vuoden $2000 \mathrm{eKr}$. tienoilla saaduilta arjalaislainoilta (s. 62). Tähän sopii hyvin Volgan ylä- ja keskijuoksun tekstiilikeramiikan ajoitus aiemmin luultua myöhemmäksi, vasta pronssikauden alkuun (s. 69), sillä neljännessä luvussa Lang osoittaa sen lähtökohdaksi kaikille Suomen, Karjalan ja Pohjois-Baltian pronssikautisille keramiikkatyyleille, joista hän käyttää yhteisnimeä Tapiolan keramiikka. Pohjoisen Baltian ja Suomen etelärannikon itämerensuomalaistumista on mahdollista seurata tarkkailemalla keramii- 
kan ja muinaislinnojen leviämissuuntia eri vuosisatoina. Arkeologisten ajoitusten on kuitenkin tällöin täsmättävä kielentutkimuksen antamien absoluuttisten ajoitusten kanssa, sillä kielihistorian ilmiöitä ei voi ajoittaa arkeologisten löytöjen pohjalta niin kuin menneinä vuosikymmeninä yritettiin tehdä (s. 60).

Teoksen loput neljä lukua esittelevät Langin nykytutkimuksen pohjalta hahmotteleman kokonaiskuvan itämerensuomalaisten esihistoriasta. Luvut neljännestä kuudenteen kattavat kauden 2000300 eKr. Itämeren rannikon ja Moskovan tienoitten välillä: neljäs luku käsittelee keramiikkaa, viides muita muinaislöytöjä ja kuudes luo synteesin kaudesta yhdistämällä kielitieteen käsityksen kantasuomen kehityksestä ja kontakteista arkeologien osoittamiin kulttuuri- ja asutusvirtauksiin. Viimeinen, seitsemäs luku ulottaa arkeologian ja kielitieteen tutkimustulosten synteesin vielä tuhat vuotta lähemmäs nykyhetkeä, vaikkakin itämerensuomen historialliseen puhumaalueeseen rajoittuen. Teoksen pääpaino onkin pronssikaudessa, josta kuva on rakennettava varsin niukkojen tietojen valossa. Rautakauden suuret kielelliskulttuuriset mullistukset Lang kuvaa paljon tiiviimmin: ne suorastaan vyöryvät tekstistä lukijan eteen.

\section{Kantasuomen sedimentit}

Itämerensuomen "tulemiset" teoksen nimessä merkitsevät kahta voimakkaitten muutosten, muuttoliikkeitten, kielenvaihtojen ja kontaktien aikakautta, joista ensimmäisen Lang ajoittaa noin välille 1200-1000 eKr. - 800-500 eKr. ja toisen välille $100 \mathrm{eKr}$ - $1000-1200 \mathrm{jKr}$. Ensimmäinen tuleminen loi edellytykset kantasuomen eriytymiselle länsikantauralista, jonka Jaakko Häkkinen (2009) on määritellyt itämerensuomen, saamen ja mordvan yhteisenä kantamuotona. Toinen tuleminen oli vuosituhannen mittainen prosessi, jonka kuluessa historiallisen ajan itämerensuomalaisten murteitten kantamuodot eriytyivät kantasuomesta.

Tapiolan keramiikka ja länsikantauralin kieli levisivät Volgan yläjuoksulta muuttoliikkeitten mukana kahteen eri suuntaan, luoteeseen Ilmajärven, Laatokan ja Äänisen suuntaan ja sieltä edelleen Fennoskandiaan sekä lounaaseen Väinäjoen ja Velikajan-Peipsin reittejä seuraten Pohjois-Baltiaan. Luoteisesta länsikantauralista kehittyi nykyisten Suomen ja Karjalan alueella kantasaame, jota Lang käsittelee vain niukasti. Päähuomio on lounaisessa liikkeessä, joka johti kontakteihin ensin balttilaisen ja sitten germaanisen kielen puhujien kanssa ja niitten kautta kantasuomen muodostumiseen. Lounaissuunnan migraatiosta Lang erottaa kolme eriaikaista aaltoa ja niitten väliset hiljaisemmat kaudet. Ensimmäisen aallon tulijat eivät kulttuuriltaan juuri eronneet Baltian metsästäjä-keräilijäväestöstä, mutta toinen, välillä 900-800 eKr. saapunut väestö harjoitti jo karjankasvatusta ja alkeellista peltoviljelyä ja asui pienissä puuvarustuksin linnoitetuissa kylissä (s. 205-210). Edellinen kulttuurikonteksti vastaa perinteistä käsitystä uralilaisten hitaasta ja rauhanomaisesta levittäytymisestä, mutta jälkimmäinen eroaa siitä täysin. Kolmas aalto vuosina 800-500 eKr. levitti tarhakalmistot Viroon (s. 211). Kulttuurivaikutuksia ja mahdollisesti väestöäkin lounaisväylä välitti vielä 300-200-luvulle eKr. saakka.

Kantasuomen vanhimmat balttilaislainat periytyvät Langin mukaan jo YläVolgalta, jossa kantabaltoslaavia puhuttiin länsikantauralin etelänaapurissa, mutta balttilaiskontaktit jatkuivat koko migraatiokauden ja pitkään sen jälkeenkin Väinäjoen vesistöalueella (s. 203-209). Kontaktit paleogermaaneihin, myöhempiin kantagermaaneihin, taas syntyivät Viron länsi- ja pohjoisrannikolla ja meren takana Lounais-Suomessa alueilla, joitten pronssikautinen materiaalinen kulttuuri on peräisin Skandinaviasta (s. 213-219). 
Rautakaudelle siirryttäessä PohjoisVirosta tuli kantasuomen keskusalue, josta kieli levisi aiempien kantasuomen murteitten päälle koko Viroon, Inkerinmaalle, Kuurinlahden rannikolle ja LounaisSuomeen, saattoipa joksikin aikaa saavuttaa sijaa Uplannissakin. Tässä itämerensuomen toisessa tulemisessa Lang erottaa kaksi peräkkäistä aaltoa, joista ensimmäinen levisi jo esiroomalaisella rautakaudella, toinen roomalaisen rautakauden aikana. Jälkimmäinen aalto ei enää peittänyt niitä kaakkoisen periferian murteita, joitten pohjalta on kehittynyt eteläviro, kaikkein eniten muista itämerensuomalaisista kielistä eroava kieli. Vuosisatoja myöhemmin myös pohjoinen itämerensuomi alkoi levitä kohti itää ja jakautua murteisiin, kunnes vasta viikinkiajalla kantasuomen leviämis- ja jakautumiskehitys ehti siihen pisteeseen, jossa puhuttiin nykyisten itämerensuomalaisten kielten pohjana olevia muinaismurteita. Kielitieteilijät kuten Terho Itkonen (1983) ja Tiit-Rein Viitso (2000) ovat pyrkineet hahmottelemaan tämän monivaiheisen prosessin päälinjoja, joille Lang nyt esittää vastineita arkeologisesta aineistosta. Näin saamme kantasuomalaisten asutushistoriasta kiehtovan, aiempaa yksityiskohtaisemman kuvan. (S. 219-260.)

\section{Kriittisiä huomioita}

Arvioin seuraavassa Langin monografian sisältöä kielihistorioitsijan näkökulmasta. En ole pätevä ottamaan kantaa hänen arkeologisesta aineistosta tekemiinsä tulkintoihin sen enempää kuin kirjassa sovellettuihin DNA-tutkimuksen tuloksiinkaan, joten suuri osa teoksen argumentaatiosta jää arvosteluni ulkopuolelle. Näkökulmani lienee kuitenkin perusteltu, onhan teoksen pääaiheena itämerensuomalaisten kielellinen menneisyys.

Tutkimushistorian kuvaus teoksessa on laaja ja johdonmukainen, mutta eräät esihistoriallisten teorioitten ensiedusta- jat ovat jääneet Langilta huomiotta, alkaen Johan Gabriel Porthanista, joka ensimmäisenä asetti kysymyksen uralilaisen kielikunnan alkuperästä. Keskustelussa jääkauden jälkeisestä ensiasutuksesta olisi voinut mainita uralilaisuuden varhaisina puoltajina arkeologi Richard Indrekon lisäksi historioitsija Väinö Wallinin ja kielitieteilijä Pekka Sammallahden. Jatkuvuusteorian hylkäämiseen johtaneista tutkimuksista Lang mainitsee arkeologi Priit Ligin julkaisun muttei historioitsija Aslak Aikion ja kielentutkija Ante Aikion laajemmin tunnettua yhteiskirjoitusta (2001). (Eräässä toisessa yhteydessä lähde kyllä huomioidaan.)

Kirjan lukemista häiritsee muutama terminologinen ongelma. Teoksessa käytetään rekonstruoiduista kantakielistä vaihtelevia vironkielisiä nimityksiä: toisinaan etuliitteenä on alg-, toisinaan prototai paleo-, joskus ei mitään. Ilmeisesti erikielisten lähteitten käytännöt ovat jääneet kirjoittajalta yhdenmukaistamatta. Tekstistä tulee esiin myös termin läänemeresoome (itämerensuomi) epäkäytännöllisyys, kun Lang on uudelleennimennyt kantasuomen eri vaiheet "kantaitämerensuomen" tai peräti vain "itämerensuomen" vaiheiksi. Esimerkiksi keskläänemeresoome on kirjassa ymmärrettävä sekä kronologisena että maantieteellisenä käsitteenä. Ehkä meidän olisi jo syytä kokonaan luopua itämerensuomesta ja kantasuomesta esimerkiksi fenniläiskielten ja kantafennin hyväksi?

Arkeologian termistössä maallikkolukijaa kiusaa muutamien ajanilmausten vaikeatulkintaisuus. Tarkoittaako esimerkiksi "toisen ajanlaskun alkua edeltäneen vuosituhannen toinen neljännes" (s. 69) vuosia $1750-1500 \mathrm{eKr}$. vai $1500-1250 \mathrm{eKr}$., ja seurasiko siis "toisen vuosituhannen toista puolikasta" jo "ensimmäisen vuosituhannen ensimmäinen puolikas"?

Häkkiseen (1996) viitaten Lang esittää kielen jakautumisen ja kielten sulautumisen yhtä tärkeinä ilmiöinä kielihistoriassa 
(s. 59). Sulautuminen eli konvergenssi on kuitenkin lähinnä näköharha, joka esiintyy siellä, missä siirtymämurteen genealoginen lähtömurre on peittynyt voimakkaan toismurteisen vaikutuksen alle. Kantakielten jakautumisten kronologioissa tulisikin kiinnittää paljon aiempaa enemmän huomiota murteutumisen erottamiseen kieliyhteyden katkeamisesta. Esimerkiksi kreikan tsakonian murre on säilyttänyt jo kaksi ja puoli vuosituhatta sitten syntyneitä eroja muuhun kreikkaan verrattuna, ilman että se kuitenkaan olisi muuttunut kreikan yleiskielen puhujille aivan käsittämättömäksi (Horrocks 2010 [1997]: 87-88). Tämä huomautus koskee oikeastaan enemmän Langin siteeraamia kielitieteilijöitä kuin häntä itseään.

Kielihistoriallisesti suuntautunut tutkija saattaisi myös mainita fylogeneettisen tutkimuksen yhteydessä (s. 65) sen ajantasaisuuden ongelmasta. Fylogeneettinen metodi ei nimittäin tuota uutta tietoa raa’an kieliaineiston analyysin vaan vasta sen etymologisen analyysin pohjalta. Metodi antaa siis muuhun kielentutkimukseen nähden ajantasaista tietoa vain, kun sen käytössä ovat etymologian uusimmat tutkimustulokset. Metodin ongelmana on, että etymologinen tieto yleensä kiertää tutkijoilta julkaisujen kautta sanakirjoihin 10-100 vuoden viipeellä.

\section{Ajoituksissa riittää vielä yhteen- soviteltavaa}

Langin etnogeneettisen kokonaisteorian keskeisin kielihistoriallinen ristiriita liittyy balttilaisten ja germaanisten lainojen ajoitukseen. Läänemeresoome tulemised (s. 45) nostaa esiin sen paradoksin, että Jorma Koivulehto tuki balttilaiskontaktien kivikautisuutta vielä osoitettuaan vanhimmat, pronssikautiset germaaniset lainat yhtä vanhoiksi kuin balttilaiset. Silti myös Lang aivan Koivulehdon tavoin ajoittaa balttilaiskontaktien alun vuosisatoja germaanisia kontakteja aiemmaksi. En näe tarvetta yhdistää sitä jo länsikantauralin ensimmäiseen lounaissuuntaiseen levittäytymiseen, sillä uudet kielelliset vaikutusaallot ovat voineet peittää aiemmat alleen. Jos näin on tapahtunut myöhäiskantasuomen levitessä roomalaisella rautakaudella, on todennäköistä, että samoin kävi jo länsikantauralille 8oo-luvulla eKr., kun idästä Baltiaan saapui toinen, ensimmäistä teknisesti paljon kehittyneempi levittäytymisaalto. Tällöin balttilaiskontaktien alkua ei tarvitsisi olettaa paljoakaan Langin 80o-luvun puoleenväliin eKr. ajoittamaa germaanikontaktien alkua (s. 214) aiemmas.

Tämä on kuitenkin vain osa ongelmasta. Varhaiskantasuomen pronssikautisten paleogermaanisten lainojen määrä (s. 216) ei nimittäin voi olla 450 vaan pikemminkin Petri Kallion (2015: 32) sanoin "muutama tusina". Useimmat Langin tähän ryhmään lukemat sanat kuuluvat äänteellisistä syistä vasta nuorempiin kerrostumiin. Vielä keskikantasuomestakin (n. 500 eKr. - 200 jKr.) on kantagermaanisia lainoja periytynyt vain alun toista sataa (Aikio \& Aikio 2001: 19-21; Kallio 2015: 26). Väärinymmärrys juontaa juurensa kaukaa tutkimushistoriasta: ainakin virolaistutkijoitten suhteen pitää paikkansa Langin (s. 57) väittämä, että "tuskin kukaan on enää 1950-luvulla epäillyt germaanisten kontaktien pronssikautisuutta tai roomalaisrautakautisuutta", vaikka ensimmäiset varmasti varhaisina pidettävät (paleo)germaaniset lainat löysi vasta Koivulehto 1970-luvulla!

Lang (s. 214) pitää erityisen intensiivisenä kantasuomalais-germaanisten kontaktien aikana paria vuosisataa pronssikauden lopulla ja paria vuosisataa rautakauden alussa. Kallio (2015: 27) taas ajoittaa useimmat kantasuomen germaaniset lainat vasta kaudelle $200-500 \mathrm{jKr}$. eli lähes vuosituhatta myöhemmiksi. Kenties alueen paleogermaanit suorastaan kantasuomalaistuivat vain yksittäisiä substraattilainoja jättäen ja voimakas kantagermaaninen lainavaikutus saatiin- 
kin rautakaudella Skandinavian suunnalta.

Balttilaiskontaktien päättymisen Lang (s. 217, 220) ajoittaa roomalaiselle rautakaudelle, mikä sopii kielitieteen antamaan kuvaan. Hän tosin olettaa, että PohjoisVirossa sijainneen kantasuomen innovaatiokeskuksen yhteydet balttilaiskontaktien alueelle Etelä-Viroon ja Pohjois-Latviaan heikkenivät esiroomalaisen rautakauden kuluessa. Tämä ei kuitenkaan välttämättä ole riidoin sen kanssa, että valtaosa kantasuomen balttilaislainoista on vasta rautakautisia (vrt. Junttila 2016). Balttilaislainojen ikäjakauma ei nimittäin ole yhtä epätasainen kuin germaanisilla lainoilla, ja vanhemmista lainakerrostumista on aina ennättänyt kadota enemmän sanoja kuin nuoremmista. Kaikkien balttilaislainojen ei myöskään tarvitse olettaa saapuneen etelästä päin. Pronssikautiset lainat on varmaankin omaksuttu superstraattina tai adstraattina jo kantabaltoslaavista, vaikka siinä ei voidakaan havaita mitään uralilaista substraattivaikutusta - Lang lienee ylitulkinnut Kalliota (2001) tällaista väittäessään (ks. s. 52). Useimmat rautakautiset balttilaislainat voivat puolestaan olla substraattivaikutusta kadonneesta murteesta, jota on saatettu käyttää hyvinkin pohjoisessa ennen kuin sen puhujat vaihtoivat kielensä kantasuomeen.

Kantaitäbaltilla eli nykyisten balttilaiskielten yhteisellä kantakielellä ei välttämättä ollut mitään kosketusta kantasuomeen. Toisin kuin Lang esittää (s. 207), itäbalttiin ei nähdäkseni kannata yhdistää myöskään jo ennen vuotta $1000 \mathrm{eKr}$. valmistettua naarmukeramiikkaa, sillä kantasuomen balttilaislainojen perusteella kantabaltoslaavin voi katsoa jakautuneen vasta viimeisen vuosituhannen puolivälin tienoilla eKr. (Junttila 2016). Tässä kohtaa Lang lienee suuresta varovaisuudestaan huolimatta langennut etnisen paradigman ansaan. Toinen kantaitäbalttiin liittyvä tulkintaongelma on vastakkaissuuntainen: Lang (s. 260) esit- tää Pietro Umberto Diniä (2014) seuraten, että lätin eriytyminen kantaitäbaltista voisi liittyä itämerensuomalaiseen vaikutukseen. Dinin väite ei voi pitää paikkaansa, sillä kaikki lätin itämerensuomalaiset lainat on saatu vasta lätin liettuasta erottaneitten äänteenmuutosten jälkeen.

Itämerensuomen "toisen tulemisen" yhteydessä olisin toivonut, että Lang olisi ottanut kantaa Janne Saarikiven (2007) kauas vepsän itäpuolelle ulottuvista paikannimistä rekonstruoimaan, sittemmin kadonneeseen itämerensuomalaiseen kielimuotoon. Kielitieteilijää jää myös askarruttamaan, eikö vepsän takana voisi sittenkin olla myös aiempi, Suomenlahden itäpuolelta pohjoiseen levinnyt itämerensuomalainen muinaismurre.

Tarpeetonta on myös liittää "seton kielen" juuret viikinkiaikaa edeltävään kontekstiin (s. 245). Kielitieteen kannaltahan setto on vain võron-seton kielen (tai eteläviron kielen võron-seton murteen) itäpää, joka eroaa murrealueen pääosasta (võron kielestä) hyvin vähän. Ero on paljon niukempi kuin kuurinmaanliivillä ja salatsinliivillä, joitten Lang (s. 248) katsoo haarautuneen kantaliivistä vasta 1400-1500-luvuilla. Settomaan paikannimistö on kauttaaltaan itäslaavilaista, joten jos alueen väestö vielä rautakaudella saattoikin puhua jotain aiempaa uralilaista kieltä, oli se varmasti ennättänyt slaavilaistua täysin ennen kuin etelävironkielinen asutus - luultavasti joskus uudella ajalla - saapui alueelle.

\section{Lopuksi}

Arvostelussani olen antanut varsin paljon tilaa Langin suurteoksesta löytämilleni ongelmakohdille ja jättänyt sen merkittävät ansiot vähemmälle huomiolle siinä toivossa, että kritiikki vie tiedettä paremmin eteenpäin kuin kehut. Todettakoon siksi vielä, että ensimmäisenä etnisen paradigman jälkeisenä synteesinä itämerensuomalaisten kielten ja kulttuu- 
rien varhaisvaiheista Läänemeresoome tulemised on kiistaton merkkiteos, joka avaa uuden, aidosti kriittisen aikakauden itämerensuomalaisten esihistorian monitieteisessä tutkimuksessa.

SANTERI JUNTTILA etunimi.sukunimi@helsinki.fi

Kirjoittaja on tutkijatohtori Helsingin yliopistossa.

\section{Lähteet}

Aikio, Ante - Aikio, Aslak 2001:

Heimovaelluksista jatkuvuuteen. Suomalaisen väestöhistorian tutkimuksen pirstoutuminen. - Muinaistutkija 4/2001 S. 2-21.

Dini, Pietro Umberto 2014: Foundations of Baltic languages. Vilnius: Vilnius University.

Horrocks, Geoffrey 2010 [1997]: Greek. A history of the language and its speakers. Toinen laitos. Oxford: Wiley-Blackwell.

HÄKKInEN, JAAKKo 2009: Kantauralin ajoitus ja paikannus. Perustelut puntarissa. - Suomalais-Ugrilaisen Seuran Aikakauskirja 92 s. 9-56.

Ḧ̈к KINEN, KaIS A 1996: Suomalaisten esihistoria kielitieteen valossa. Helsinki: Suomalaisen Kirjallisuuden Seura.

Itkonen, Terho 1983: Välikatsaus suomen kielen juuriin. - Virittäjä 87 s. 190-229, 349-386.

Junttila, SAnteri 2016: Die baltischslawische Frage im Lichte der alten baltischen Lehnwörter des Ostseefinnischen. - Baltistica 51 s. 217-238.

Kallio, Petri 2001: Phonetic uralisms in
Indo-European? - Christian Carpelan, Asko Parpola \& Petteri Koskikallio (toim.), Early contacts between Uralic and Indo-European. Linguistic and archaeological considerations s. 221-234. SuomalaisUgrilaisen Seuran Toimituksia 242. Helsinki: Suomalais-Ugrilainen Seura. 2015: The stratigraphy of Germanic loanwords in Finnic. - John Ole Askedal \& Hans Frede Nielsen (toim.), Early Germanic languages in contact s. 23-38. Amsterdam: John Benjamins.

Lehtinen, TAPAni 2007: Kielen vuosituhannet. Suomen kielen kehitys kantauralista varhaissuomeen. Helsinki: Suomalaisen Kirjallisuuden Seura.

Ligi, PriIt 1995: Ühiskondlikest oludest Eesti alal hilispronksi- ja rauaajal. - Valter Lang (toim.), Eesti arheoloogia historiograafilisi, teoreetilisi ja kultuuriajaloolisi aspekte s. 182-270. Tallinn: Teaduste Akadeemia kirjastus.

SAARIKIVI, JANNE 2007: On the Uralic substrate toponymy of Arkhangelsk region. Problems of research methodology and ethnohistorical interpretation - Ritva Liisa Pitkänen \& Janne Saarikivi (toim.), Borrowing of place names in the Uralian languages s. 45-109. Onomastica Uralica 4. Debrecen \& Helsinki: Magyar Nyelvtudományi Tanszék.

Salminen, Timo 2013: Arkeologia tieteenä. Tutkijoiden keskustelua 1900-luvun alkukymmeninä. - Muinaistutkija 2/2013 S. $25-44$.

Virtso, Tirt-Rein 2000: Finnic affinity. - Congressus nonus internationalis Fenno-Ugristarum Tallinnae habitus 7.-13.8.200o s. 153-178. Pars I. Orationes plenariae. Orationes publicae. Tartu. 